\title{
PENGARUH PENERAPAN PRINSIP LEADERSHIP, EMPLOYEE INVOLVEMENT, DAN CONTINUOUS IMPROVEMENT TERHADAP KEPUASAN KERJA KARYAWAN
}

\author{
THE EFFECT OF APPLYING THE PRINCIPLES OF LEADERSHIP, EMPLOYEE INVOLVEMENT, AND \\ CONTINUOUS IMPROVEMENT ON EMPLOYEE JOB SATISFACTION
}

Aderia Putri Prasanti, Nyoman Anita Damayanti

Fakultas Kesehatan Masyarakat, Universitas Airlangga, Surabaya

E-mail: aderia.prasanti@gmail.com

\begin{abstract}
Job satisfaction rate of Rumah Sakit Mata Undaan Surabaya (RSMU)'s employees increasedfrom $76,92 \%$ to $78,92 \%$ in 2012-2013. Unfortunately, in 2014 this rate decreased to $74,91 \%$. The target set by management is $80 \%$. Therefore, job satisfaction rate of RSMU's employees has not reached the target. The aim of this study is to analyze the influence of leadership, employee involvement, and continuous improvement principle implementationtowards the job satisfaction of RSMU's employees. This study used observational method with cross sectional design. The data was obtained through questionnaire with simple random sampling involving 90 employees as the sample of the research. The next step is analyzing the data analytically by using logistic regression test univariate $(\alpha=0,05)$ to examine the influence of leadership, employee involvement, and continuous improvement principle implementation towards the employee's job satisfaction. The test result indicates that there are influences of two principles implementation towards the employee's job satisfaction. Those principles, on the one hand, are leadership (sig=0,002) and continuous improvement $(s i g=0,006)$. On the other hand, the implementation of employee involvement does not affect the job satisfaction.
\end{abstract}

Keywords :Employee job satisfaction, leadership, employee involvement, continuous improvement

\section{PENDAHULUAN}

Robbins (2001) menyatakan kepuasan kerja merupakan suatu sikap umum terhadap pekerjaan seseorang atau selisih antara banyaknya ganjaran yang diterima seorang pegawai dan banyaknya yang mereka yakini apa yang seharusnya mereka terima. Terdapat beberapa faktor yang mendorong kepuasan kerja yaitu ganjaran atau upah, kerja yang secara mental menantang, kondisi kerjadan rekan kerja yang mendukung (Robbins, 2001). Best dan Thurston (2004) menyatakan bahwa kepuasan kerja karyawan ditentukan oleh tiga faktor yaitu faktor lingkungan kerja, faktor individu karyawan, dan faktor organisasi.

Beberapa penelitian juga menyebutkan bahwa terdapat pengaruh penerapan beberapa prinsip Total Quality Management terhadap kepuasan kerja karyawan.Bhaskara (2011) menyatakan bahwa penerapan prinsip Total Quality Management yang terdiri dari employee involvement, continuous improvement, customer focus, teamwork, serta training and education memiliki pengaruh yang siginifikan baik secara simultan maupun parsial terhadap kepuasan kerja karyawan.Menurut Boselie dan Van der Wiele (2001) terdapat beberapa prinsip Total Quality Management yang memiliki pengaruh positif terhadap kepuasan kerja karyawan yaitu leadership kerjasama, informasi gaji, kondisi kerja, dan penetapan tujuan.

Hasil penelitian ljaz (2011) menyebutkan bahwa penerapan prinsip leadership, training and education, reward and recognition employee empowerment, dan cooperation dalam Total Quality Management memiliki hubungan yang positif terhadap kepuasan kerja karyawan. Aryanti (2002) menyatakan bahwa terdapat hubungan yang positif antara penerapan prinsip continuous improvement dalam Total Quality Management dengan kepuasan kerja karyawan.Hasil 
survei pendahuluan dalam penelitian ini menunjukkan bahwa Rumah Sakit Mata Undaan (RSMU) Surabaya telah lama menerapkan prinsip Total Quality Manajemen seperti leadership, employee involvement, dan continuous improvement dalam aktivitas manajerialnya.

Rumah Sakit Mata UndaanSurabaya secara rutin setiap tahunnya mengadakan survei kepuasan kerja karyawan. Berdasarkan data sekunder yang ada diketahui bahwa kepuasan kerja karyawan secara keseluruhan sempat mengalami kenaikan di tahun 2012 yakni 76,92\% menjadi 78,92\%di tahun 2013.Namun demikian tingkat kepuasan kerja karyawan RSMUkembali mengalami penurunan di tahun 2014 menjadi 74,91\%. Target kepuasan kerja karyawan yang ditetapkan pihak manajemen adalah $80 \%$. Dengan demikian dapat dikatakan bahwa tingkat kepuasan kerja karyawan Rumah Sakit Mata Undaan Surabaya belum mencapai target di tahun 2012-2013.

Penelitian ini bertujuan menguji pengaruh penerapan prinsip leadership, employee involvement, dan continuous improvement terhadap kepuasan kerja karyawan. Hasil dari penelitian ini diharapkan dapat menjadi masukan kepada pihak manajemen untuk meningkatkan kepuasan kerja karyawan hingga mencapai atau melebihi target yang ditetapkan.

\section{PUSTAKA}

Kepuasan kerja merupakan suatu sikap umum terhadap pekerjaan seseorang yang merupakan selisih antara banyaknya ganjaran yang diterima seorang pegawai denganharapan mereka sebenarnya (Robbins, 2001).Kepuasan kerja merupakan suatu sikap positif yang menyangkut penyesuaian diri yang sehat dari para karyawan terhadap kondisi dan situasi kerja, termasuk di dalamnya kondisi fisik, upah, dan kondisi psikologi (Arnold dan Feldman, 1988).

Ada dua cara pengukuran kepuasan kerja, yaitu mengukur kepuasan kerja secara keseluruhan dan mengukur kepuasan kerja terhadap aspek kerja.Pengukuran kepuasan kerja terhadap aspek kerja dilakukan dengan cara menjumlahkan kepuasan terhadap aspek kerja tersebut sehingga diperoleh kepuasan kerja secara keseluruhan (Wahyudi, 2010). Kedua jenis pengukuran tersebut digunakan sesuai dengan tujuannya.Pembuat kebijakan mungkin tertarik pada kepuasan kerja secara keseluruhan dari unit kerja tertentu atau untuk mengetahui perubahan kepuasan kerja secara keseluruhan dari waktu ke waktu. Sebaliknya pengukuran kepuasan terhadap aspek kerja akan dipilih apabila organisasi meningkatkan kepuasan aspek kerja karyawannya atau mencari penjelasan mengapa seseorang meninggalkan pekerjaannya. Instrumen yangdigunakan untuk mengukur kepuasan kerja secara keseluruhan misalnya Gallup Poll Question, Hoppock Job Satisfaction Scale, dan Job in General Faces Scale. Instrumen yang digunakan untuk mengukur kepuasan terhadap aspek kerja misalnya Job Descriptio Index dan MinnesotaSatisfaction Quetionnaire (Scarpello dan Campbell, 1983).

Tujuan dari kepemimpinan dalam manajemen kualitas adalah untuk meningkatkan performansi manusia dan mesin, memperbaiki kualitas yang ada, 
meningkatkan output dan produktivitas, serta secara simultan mampu menciptakan kebanggan kerja (pride of workmanship) bagi pekerja.Menurut Gasperz (2005) menyebutkan 4 tugas pemimpin dalam manajemen kualitas yakni mengembangkan visi serta menetapkan arah dan strategi perusahaan, mengkomunikasikan tujuan melalui pernyataan dan tindakan nyata, memberikan motivasi bagi karyawan untuk mengatasi hambatan dalam perubahan menuju perbaikan, serta menciptakan perubahan bagi kemajuan perusahaan.

Konsep employee involvement berarti bahwa setiap individu bertanggung jawab untuk tindakannya sehingga setiap orang harus bertanggung jawab untuk mengidentifikasi tindakan-tindakan yang diperlukan dan kemudian bertindak tanpa perlu diarahkan atau diperintah secara langsung. Praktekpraktek manajemen tradisional adalah bersifat sentralisasi dan mengembangkan

struktur wewenang yang kaku, sedangkan TQM menerapkan struktur organisasi desentralisasi. Dengan demikian, jika karyawan dari organisasi telah terlibat dan mengadopsi ide-ide tanggung jawab pada sumber penyebab masalah, maka manajemen harus mendelegasikan tanggung jawab dan wewenang kepada karyawan yang telah dapat didayagunakan itu.

Continous improvement mindset terdiri dari paradigma improvement berkelanjutan, keyakinan dasar terhadap improvement berkelanjutan, dan nilai-nilai dasar yang melandasi improvement berkelanjutan.Continous improvement mengharuskan personel mengetahui dimana mereka sekarang berada, kemana mereka ingin menuju di masa yang akan datang, dan kemajuan yang telah mereka capai dalam mewujudkan tujuan mereka. Continuous improvement dalam sistem manajemen diwujudkan dalam bentuk organisasi sebagai destabilizer, de-jobbed organization, teamwork, cross-functional approach, kualitas, keandalan, kecepatan, dan efisiensi biaya.

\section{METODE}

Penelitian ini termasuk dalam penelitian observasional analitik dengan rancang bangun bersifat cross sectional. Teknik pengumpulan data dilakukan dengan menggunakan kuesioner.Terdapat dua jenis variabel dalam penelitian ini yakni variabel independen dan variabel dependen. Variabel independen terdiri dari penerapan prinsip leadership, employee involvement, dan continuous improvement. Variabel dependen dalam penelitian ini adalah kepuasan kerja karyawan.Masing-masing variabel independen diuji pengaruhnyaterhadap kepuasan kerja karyawan dengan menggunakan uji regresi logistik univariat.

Populasi dalam penelitian ini adalah karyawan Rumah Sakit Mata Undaan Surabaya yang berjumlah 115 orang.Besar sampel diperoleh berdasarkan perhitungan menggunakan rumus simple random sampling.Jumlah sampel dalam penelitian ini adalah 90 orang.Data primer diperoleh dari hasil pengisian kuesioner mengenai penilaian karyawan terhadap penerapan prinsip TQM yang terdiri dari leadership, employee involvement, dan continuous improvement, serta kepuasan kerja karyawan itu sendiri. 


\section{HASIL DAN PEMBAHASAN}

\section{Kepuasan Kerja Karyawan}

Gibson et al. (2009) menyatakan bahwa kepuasan kerja merupakan suatu sikap pekerja mengenai pekerjaannya yang dihasilkan dari persepsi mereka terhadap pekerjaannya berdasarkan faktor yang terdapat dalam lingkungan kerja seperti gaya penyelia, kebijakan dari prosedur, afiliasi kelompok kerja, kondisi kerja, dan manfaat lainnya bagi pekerja. Pada tabel 1.disajikan hasil pengukuran kepuasan kerja karyawan.

Tabel 1 Hasil Pengukuran Kepuasan Kerja Karyawan Rumah Sakit Mata Undaan Surabaya

\begin{tabular}{ccc}
\hline $\begin{array}{c}\text { Kepuasan } \\
\text { Kerja }\end{array}$ & Frekuensi & $\begin{array}{c}\text { Persentase } \\
\text { (\%) }\end{array}$ \\
\hline Tinggi & 70 & 77,8 \\
\hline Rendah & 20 & 22,2 \\
\hline Total & 90 & 100 \\
\hline
\end{tabular}

Tabel 1 menunjukkan bahwa sebagian besar karyawan yakni $77,8 \%$ atau 70 dari 90 karyawanmemiliki tingkat kepuasan kerja yang tinggi. Namun demikian masih terdapat $22,2 \%$ atau 20 dari 90 orang karyawan yang memiliki tingkat kepuasan kerja yang rendah. Teori Pareto menyebutkan aturan $80 / 20$, yang artinya $80 \%$ masalah (cacat) ditimbulkan oleh $20 \%$ penyebab (Pitsoulis, 2008). Dalam hal ini kepuasan kerja karyawan yang rendah mencapai $22,2 \%$ sehingga hal tersebut perlu menjadi perhatian khusus bagi pihak manajemen agar tidak menimbulkan masalah yang lebih besar terhadap kepuasan kerja karyawan.

Tingkat kepuasan kerja karyawan diperoleh berdasarkan perolehan skor pertanyaan indikator kepuasan kerja yang berasal dari faktor organisasi maupun faktor lingkungan kerja.Indikator kepuasan kerja karyawan yang berasal dari faktor organisasi terdiri dari struktur penggajian, insentif, tunjangan karyawan, jaminan kesehatan, jaminan pensiun, kebijakan manajemen, keterlibatan dalam organisasi, pelatihan, penghargaan atas prestasi, dan pengembangan karier.Sedangkan indikator kepuasan kerja dari faktor lingkungan kerja meliputi beban kerja, waktu kerja, kemanan tempat kerja, hubungan antar unit kerja, hubungan antar karyawan, hubungan dengan atasan, kelengkapan alat kerja, dan suasana tempat kerja.Pada tabel 2.disajikan hasil pengukuran kepuasan terhadap faktor organisasi. Selanjutnya pada tabel 3.disajikan hasil pengukuran kepuasan terhadap faktor lingkungan kerja.

Tabel 2 menunjukkan sebagian besar karyawan memiliki tingkat kepuasan yang tinggi terhadap beberapa indikator kepuasan kerja yang berasal dari faktor organisasi. Namun demikian jika diperhatikan kembali masih terdapat beberapa indikator kepuasan kerja yang masih memiliki kategori hasil rendah dengan persentase lebih dari $20 \%$. Indikator yang dimaksud antara lainstruktur penggajian, tunjangan karyawan, jaminan kesehatan, tunjangan hari tua, kebijakan manajemen, keterlibatan dalam organisasi, penghargaan atas prestasi, pengembangan karier, serta pelatihan dan pendidikan. Pihak manajemen perlu memperhatikan dan meninjau kembali sistem terkait beberapa indikator tersebut.Hal ini penting dilakukan untuk mencegah dampak negatif terhadap kepuasan kerja karyawan yang sebenarnya sudah tinggi. 
Tabel 2 Hasil Pengukuran Indikator Kepuasan Kerja Karyawan yang Berasal dari Faktor Organisasi

\begin{tabular}{|c|c|c|c|}
\hline Indikator & Kepuasan & Frekuensi & $(\%)$ \\
\hline \multirow{3}{*}{ Struktur Penggajian } & Tinggi & 63 & 70 \\
\hline & Rendah & 27 & 30 \\
\hline & Total & 90 & 100 \\
\hline \multirow{3}{*}{ Insentif } & Tinggi & 72 & 80 \\
\hline & Rendah & 18 & 20 \\
\hline & Total & 90 & 90 \\
\hline \multirow{3}{*}{ Tunjangan Karyawan } & Tinggi & 63 & 70 \\
\hline & Rendah & 27 & 30 \\
\hline & Total & 90 & 100 \\
\hline \multirow{3}{*}{ Jaminan Kesehatan } & Tinggi & 55 & 61,1 \\
\hline & Rendah & 35 & 38,9 \\
\hline & Total & 90 & 100 \\
\hline \multirow{3}{*}{ Tunjangan hari tua } & Tinggi & 68 & 75,6 \\
\hline & Rendah & 22 & 24,4 \\
\hline & Total & 90 & 100 \\
\hline \multirow{3}{*}{ Kebijakan manajemen } & Tinggi & 65 & 72,2 \\
\hline & Rendah & 25 & 27,8 \\
\hline & Total & 90 & 90 \\
\hline \multirow{3}{*}{$\begin{array}{l}\text { Keterlibatan dalam } \\
\text { organisasi }\end{array}$} & Tinggi & 71 & 78,9 \\
\hline & Rendah & 19 & 21,1 \\
\hline & Total & 90 & 100 \\
\hline \multirow{3}{*}{$\begin{array}{l}\text { Penghargaan atas } \\
\text { prestasi }\end{array}$} & Tinggi & 64 & 71,1 \\
\hline & Rendah & 26 & 28,9 \\
\hline & Total & 90 & 100 \\
\hline \multirow{3}{*}{ Pengembangan karier } & Tinggi & 62 & 68,9 \\
\hline & Rendah & 28 & 31,1 \\
\hline & Total & 90 & 100 \\
\hline \multirow{3}{*}{ Pelatihan dan Pendidikan } & Tinggi & 68 & 75,6 \\
\hline & Rendah & 22 & 24,4 \\
\hline & Total & 90 & 100 \\
\hline
\end{tabular}

Pada tabel 3 dapat diketahui bahwa sebagian besar responden memiliki tingkat kepuasan yang tinggi terhadap indikator kepuasan kerja yang berasal dari faktor lingkungan kerja. Namun demikian masih terdapat beberapa indikator yang memiliki kategori hasil rendah dengan persentase lebih dari $20 \%$ yakni keamanan tempat kerja dan suasana tempat kerja.Hal tersebut tentu harus menjadi perhatian khusus bagi pihak manajemen sebagai langkah antisipasi untuk mencegah timbulnya masalah kepuasan kerja karyawan.

Luthans (2006) mengemukakan bahwa karyawan yang tingkat kepuasannya tinggi cenderung memiliki kesehatan fisik yang lebih baik, mempelajari tugas yang berhubungan dengan pekerjaan baru dengan lebih cepat, memiliki sedikit kecelakaan kerja, mengajukan lebih sedikit keluhan, meningkatkan kinerja, mengurangi pergantian karyawan dan ketidakhadiran. Kepuasan kerja karyawan RSMU yang tinggi seharusnya dapat dimanfaatkan oleh pihak manajemen dengan baik. Seperti yang telah dibahas sebelumnya bahwa karyawan yang memiliki tingkat kepuasan kerja yang tinggi memiliki kecenderungan peningkatan kinerja yang tentunya akan berdampak positif terhadap peningkatan mutu rumah sakit.

Namun demikian pihak manajemen juga perlu meninjau kembali sistem terkait beberapa indikator kepuasan kerja karyawan dengan kategori hasil rendah yang mencapai lebih dari $20 \%$. Hal ini penting dilakukan untuk mencegah dampak negatif terhadap kepuasan kerja karyawan sebenarnya sudah tinggi. 
Tabel 3 Hasil Pengukuran Indikator Kepuasan Kerja Karyawan yang Berasal dari Faktor Lingkungan Kerja

\begin{tabular}{|c|c|c|c|}
\hline Indikator & Kepuasan & Frekuensi & $(\%)$ \\
\hline \multirow{3}{*}{ Beban Kerja } & Tinggi & 83 & 92,2 \\
\hline & Rendah & 7 & 7,8 \\
\hline & Total & 90 & 100 \\
\hline \multirow{3}{*}{ Waktu Kerja } & Tinggi & 83 & 92,2 \\
\hline & Rendah & 7 & 7,8 \\
\hline & Total & 90 & 100 \\
\hline \multirow{3}{*}{ Kemanan Tempat Kerja } & Tinggi & 68 & 75,6 \\
\hline & Rendah & 22 & 24,4 \\
\hline & Total & 90 & 100 \\
\hline \multirow{3}{*}{$\begin{array}{l}\text { Hubungan Antar Unit } \\
\text { Kerja }\end{array}$} & Tinggi & 80 & 88,9 \\
\hline & Rendah & 10 & 11,1 \\
\hline & Total & 90 & 100 \\
\hline \multirow{3}{*}{$\begin{array}{l}\text { Hubungan antar } \\
\text { Karyawan }\end{array}$} & Tinggi & 88 & 97,8 \\
\hline & Rendah & 2 & 2,2 \\
\hline & Total & 90 & 100 \\
\hline \multirow{3}{*}{ Hubungan dengan Atasan } & Tinggi & 78 & 86,7 \\
\hline & Rendah & 12 & 13,3 \\
\hline & Total & 90 & 100 \\
\hline \multirow{3}{*}{ Kelengkapan Alat Kerja } & Tinggi & 77 & 85,6 \\
\hline & Rendah & 13 & 14,4 \\
\hline & Total & 90 & 100 \\
\hline \multirow{3}{*}{ Suasana Tempat Kerja } & Tinggi & 68 & 75,6 \\
\hline & Rendah & 22 & 24,4 \\
\hline & Total & 90 & 100 \\
\hline \multirow{3}{*}{ Beban Kerja } & Tinggi & 83 & 92,2 \\
\hline & Rendah & 7 & 7,8 \\
\hline & Total & 90 & 100 \\
\hline \multirow{3}{*}{ Waktu Kerja } & Tinggi & 83 & 92,2 \\
\hline & Rendah & 7 & 7,8 \\
\hline & Total & 90 & 100 \\
\hline \multirow{3}{*}{ Kemanan Tempat Kerja } & Tinggi & 68 & 75,6 \\
\hline & Rendah & 22 & 24,4 \\
\hline & Total & 90 & 100 \\
\hline \multirow{3}{*}{$\begin{array}{l}\text { Hubungan Antar Unit } \\
\text { Kerja }\end{array}$} & Tinggi & 80 & 88,9 \\
\hline & Rendah & 10 & 11,1 \\
\hline & Total & 90 & 100 \\
\hline \multirow{3}{*}{$\begin{array}{l}\text { Hubungan antar } \\
\text { Karyawan }\end{array}$} & Tinggi & 88 & 97,8 \\
\hline & Rendah & 2 & 2,2 \\
\hline & Total & 90 & 100 \\
\hline \multirow{3}{*}{ Hubungan dengan Atasan } & Tinggi & 78 & 86,7 \\
\hline & Rendah & 12 & 13,3 \\
\hline & Total & 90 & 100 \\
\hline \multirow{3}{*}{ Kelengkapan Alat Kerja } & Tinggi & 77 & 85,6 \\
\hline & Rendah & 13 & 14,4 \\
\hline & Total & 90 & 100 \\
\hline \multirow{3}{*}{ Suasana Tempat Kerja } & Tinggi & 68 & 75,6 \\
\hline & Rendah & 22 & 24,4 \\
\hline & Total & 90 & 100 \\
\hline
\end{tabular}

Pekerja yang tidak puas cenderung bersikap yang kontraproduktif. Ketidakpuasan juga alasan menentang dalam hubungannya dengan utama seseorang meninggalkan organisasi (Hughes kepemimpinan dan terlibat dalam berbagai prilaku et al.,2012). 
Tabel 4 Hasil Pengukuran Penerapan Prinsip Leadership, Employee Involvement, dan Continuous Improvement

\begin{tabular}{llll}
\hline Variabel & Hasil & Jumlah & Persentase (\%) \\
\hline \multirow{2}{*}{ Leadership } & Baik & 83 & 92,2 \\
& Kurang Baik & 7 & 7,8 \\
& Total & 90 & 100 \\
\hline \multirow{2}{*}{ Employee Involvement } & Baik & 77 & 85,6 \\
& Kurang Baik & 13 & 14,4 \\
& Total & 90 & 100 \\
\hline \multirow{2}{*}{ Continuous Improvement } & Baik & 84 & 93,3 \\
& Kurang & 6 & 6,7 \\
& Baik & 100 & 100 \\
\hline
\end{tabular}

\section{Penerapan Prinsip Leadership, Employee}

\section{Involvement, dan Continuous Improvement}

Hasil pengukuran penerapan prinsip leadership, employee involvement, dan continuous improvement diperoleh berdasarkan penilaian karyawan terhadap penerapan ketiga prinsip tersebut.Hasil penilaian karyawan dikelompokkan ke dalam dua kategori hasil yakni baik dan kurang baik.

Tabel 4 menunjukkan bahwa sebagian besar respondenyakni $92,2 \%$ menilai bahwa penerapan prinsip leadership di Rumah Sakit Mata Undaan Surabaya termasuk dalam kategori baik. Hasil tersebut diperoleh berdasarkan penilaian karyawan atas peran kepemimpinan yang dijalankan oleh pihak manajemen. Peran yang dimaksud antara lain keaktifan pengembangan, penetapan strategi, serta komunikasi visi dan misi kepada karyawan dan dorongan motivasi yang diberikan pihak manajemen kepada karyawan. Yasin (2001) mengemukakan bahwa keberhasilan kegiatan usaha pengembangan organisasi, sebagian besar ditentukan oleh kualitas kepemimpinan atau pengelolanya dan komitmen pimpinan puncak organisasi untuk investasi energi yang diperlukan maupun usaha-usaha pribadi pimpinan.Oleh karena itu penerapan prinsip leadership di RSMU yang temasuk dalam kategori baik seharusnya mampu membawa dampak yang positif bagi kemajuan rumah sakit.

Tabel 4.juga menunjukkan bahwa sebagian besar responden atau $85,6 \%$ menilai penerapan prinsip employee involvement termasuk dalam kategori baik. Hasil tersebut diperoleh berdasarkan penilaian karyawan atas keaktifan partisipasinya dalam upaya peningkatan mutu rumah sakit.Partisipasi itu diwujudkan dalam memberikan saran terkait peningkatan mutu, serta aktif terlibat dalam setiap kegiatan dan pelatihan terkait peningkatan mutu rumah sakit.Masing-masing aspek tersebut dinilai termasuk dalam kategori bagus oleh sebagian besar responden.Keterlibatan yang tinggi sangat dibutuhkan karena kesuksesan peningkatan mutu rumah sakit akan sangat tergantung pada karyawan. Setiap pengembangan TQM tergantung pada orang-orang yang sedang mengerjakan pekerjaan-pekerjaan produktif, sedang bekerja lebih cerdas, dan sedang membantu meningkatkan sistem itu (Lowery, 2000).

Selanjutnya berdasarkan hasil penelitian, dapat diketahui pula bahwa sebagian besar responden atau $93,3 \%$ menilai penerapan prinsip continuous improvement di Rumah Sakit Mata Undaan Surabaya termasuk dalam kategori baik. Hasil 
tersebut diperoleh berdasarkan penilaian karyawan atas keaktifan pengembangan indikator mutu, penilaian kinerja, penyelenggaraan kegiatan peningkatan kompetensi karyawan, dan pemanfaatan saran dan kritik dari pasien. Dengan adanya perbaikan kualitas secara terus menerus, seperti penilaian kinerja dan pemanfaatan umpan balik pasien maka manajemen kualitas dari rumah sakit akan tetap terjaga (Baskara, 2011).

\section{Pengaruh Penerapan Prinsip Leadership Terhadap Kepuasan Kerja Karyawan}

Pengaruh penerapan prinsip leadership terhadap kepuasan kerja karyawan berdasarkan hasil uji regresi logistik univariat memiliki signifikansi sebesar 0,002 yang berarti lebih kecil dari $\alpha(0,05)$. Dengan demikian dapat disimpulkan bahwa terdapat pengaruh antara variabel penerapan prinsip leadership terhadap kepuasan kerja karyawan.Nilai Exp. (B) yang diperoleh adalah 0,344.Koefisien ini menunjukkan kuatnya pengaruh penerapan prinsip leadershipterhadap kepuasan kerja karyawan. Arti dari Exp. $(B)=0,344$ adalah kemungkinan karyawan yang menilai penerapan prinsip continuous improvement termasuk dalam kategori baik akan mengalami kepuasan kerja yang tinggi sebesar 2,91 $(1 / 0,344)$ kali lebih besar dibandingkan dengan karyawan yang menilai penerapan prinsip leadershiptermasuk dalam kategori kurang baik. Dengan demikian secara sederhana dapat disimpulkan bahwa penerapan prinsip leadership yang baik memiliki kecenderunganmenciptakan kepuasan kerja yang tinggi pada karyawan. Hasil penelitian ini sesuai dengan hasil penelitian yang dilakukan oleh ljaz (2012) yang menyatakan bahwa terdapat hubungan yang positif antara penerapan kepemimpinan dalam TQM terhadap kepuasan kerja karyawan.Penerapan leadership di setiap level dalam organisasi merupakan kunci untuk menciptakan lingkungan kerja yang sehat dan memotivasi karyawan mencapai keuntungan bagi perusahaan (Lawler et al. 1998).

Siagian (2002) mengemukakan bahwa peranan pemimpin atau kepemimpinan dalam organisasi atau perusahaan ada tiga bentuk yaitu peranan yang bersifat interpersonal, peranan yang bersifat informasional, dan peran pengambilan keputusan.Berpengaruhnya penerapan prinsip leadership terhadap kepuasan kerja karyawan di Rumah Sakit Mata Undaan Surabaya menjelaskan bahwa pimpinan atau dalam hal ini pihak manajemen telah menjalankan perannya dengan baik. Peranan yang dimaksud antara lain adalah peranan yang bersifat interpersonal, informasional, dan peran pengambilan keputusan. Peran interpersonal banyak terkait dengan hubungan yang terjalin antara karyawan dan pihak manajemen dimana hal tersebut menjadi salah satu indikator kepuasan kerja karyawan.Begitu pula dengan peran informasional dan pengambilan keputusan.Pihak manajemen yang aktif mengkomunikasikan informasi dan hal terkait pengambilan keputusan terbukti memberikan dampak yang positif bagi kepuasan kerja karyawan RSMU (Prasanti, 2015).

\section{Pengaruh Penerapan Prinsip Employee Involvement Terhadap Kepuasan Kerja Karyawan}

Pengaruh penerapan prinsip employee
involvement terhadap kepuasan kerja karyawan
berdasarkan hasil uji regresi logistik memiliki


signifikansi0,427 yang berarti lebih besar dari $\alpha$ $(0,05)$. Dengan demikian dapat disimpulkan bahwa tidak terdapat pengaruh antara variabel penerapan prinsip employee involvement terhadap kepuasan kerja karyawan.

Hasil dari penelitian ini berlawanan dengan teori yang dikemukakan Lawler et al. (1998) yang menyatakan keterlibatan karyawan merupakan kunci motivasi bagi terciptanya kepuasan kerja karena hal tersebut menciptakan lingkungan dalam organisasi dimana karyawan terlibat dan berpartisipasi dalam aktivitas penetapan keputusan. Semakin tinggi keterlibatan karyawan dalam pekerjaan mereka membantu meningkatkan komitmen dan kinerja karyawan.

Dalam kaitannya dengan faktor penentu kepuasan kerja beberapa peneliti seperti Judge dan Bono (2001) dan Best dan Thurston (2004), sertaChing, Ying-Ling dan Rong-Da (2000), mengemukakan bahwa variabel kepuasan kerja dapat dikategorikan menjadi dua dimensi yaitu fitur internal dan fitur eksternal. Fitur internal yaitu kesempatan untuk menunjukkan kemampuan, rasa prestasi yang diperoleh dari pekerjaan, nilai-nilai etis dari pekerjaan, dan peluang untuk menyediakan layanan.Fitur eksternal yaitu terdiri dari deskripsi pekerjaan, gaji, dan kompensasi, promosi, fasilitas, peralatan, dan lingkungan kerja. Hal tersebut menjelaskan banyak faktor lain di luar keterlibatan karyawan yang dapat berpengaruh terhadap kepuasan kerja karyawan Rumah Sakit Mata Undaan Surabaya.

\section{Pengaruh Penerapan Prinsip Continuous} Improvement Terhadap Kepuasan Kerja Karyawan

Pengaruh penerapan prinsip continuous improvement terhadap kepuasan kerja karyawan berdasarkan hasil uji regresi logistik univariat memiliki signifikansisebesar 0,006 yang berarti lebih kecil dari $\alpha(0,05)$. Dengan demikian dapat disimpulkan bahwa terdapat pengaruh penerapan prinsip continuous improvement terhadap kepuasan kerja karyawan.Nilai Exp. (B) yang diperoleh adalah 0,43 . Koefisien ini menunjukkan kuatnya pengaruh penerapan prinsip continuous improvement terhadap kepuasan kerja karyawan. Arti dari Exp. $(B)=0,43$ adalah kemungkinan karyawan yang menilai penerapan prinsip continuous improvement termasuk dalam kategori baik akan mengalami kepuasan kerja yang tinggi sebesar $2,32(1 / 0,43)$ kali lebih besar dibandingkan dengan karyawan yang menilai penerapan prinsip continuous improvement termasuk dalam kategori kurang baik. Dengan demikian secara sederhana dapat disimpulkan bahwa penerapan prinsip continuous improvement yang baik memiliki kecenderungan menciptakan kepuasan kerja yang tinggi pada karyawan.Penemuan tersebut mendukung hasil penelitian Bhaskara (2011) yang menyatakan bahwa faktor continuous improvement ternyata berpengaruh terhadap kepuasan kerja karyawan.

Upaya continuous improvement yang dilakukan RSMU meliputi perbaikan atau pengembangan indikator mutu, penilaian kinerja karyawan, pelatihan, dan pemanfaatan saran dan kritik pasien.Pengembangan indikator mutu dan penilaian 
kinerja yang ditetapkan pihak Rumah Sakit Mata Undaan Surabaya bertujuan untuk menstimulasi karyawan untuk bekerja lebih baik dan memberikan tantangan yang lebih dalam pekerjaan mereka.Karyawan dituntut selalu memberikan performa yang terbaik sesuai indikator mutu dan standar penilaian kinerja yang ada.Robbins (1996) menyatakan karyawan cenderung lebih menyukai pekerjaan-pekerjaan yang memberi mereka kesempatan untuk menggunakan keterampilan dan kemampuan mereka serta menawarkan beragam tugas, kebebasan dan umpan balik mengenai keberhasilan mereka. Pada kondisi tantangan yang sesuai dengan tingkat kemampuan karyawan, mereka akan mengalami kesenangan dan kepuasan.

Penerapan prinsip continuous improvement yang dilakukan pihak manajemen juga terkait keaktifan pihak mengadakan kegiatan peningkatan/pelatihan kompetensi karyawan dalam peningkatan mutu rumah sakit. Adanya pelatihan akan membantu karyawan untuk memahami suatu pengetahuan praktis dan penerapannya untuk meningkatkan keterampilan yang dimilikinya, sehingga dapat tercipta suatu dimana karyawan bisa memperoleh dan mempelajari baik sikap, kemampuan, pengetahuan, dan perilaku spesifik yang berkaitan dengan pekerjaannya (Handoko danTjiptono, 1998). Hal ini tentu akan menimbukan kepuasan tersendiri bagi seorang karyawan.

\section{SIMPULAN}

Hasil uji pengaruhmenunjukkan bahwa variabel yang berpengaruh terhadap kepuasan kerja karyawan adalah leadership dan continuous
improvement.Sedangkan variabel employee involvement tidak berpengaruh terhadap kepuasan kerja karyawan.

Peningkatan kepuasan kerja karyawan dapat dilakukan dengan meningkatkan penerapan prinsip leadership dengan cara dijalankannya peran kepemimpinan dengan baik. Peran yang dimaksud adalah peran yang bersifat interpersonal, informasional, dan pengambilan keputusan.Selanjutnya upaya peningkatan kepuasan kerja juga dapat dilakukan dengan meningkatkan penerapan prinsip continuous improvement melalui dijalankannya pengembangan indikator mutu, penilaian kinerja, pemanfaatan saran dan kritik pasien, dan pelatihan dan pendidikan.

\section{DAFTAR PUSTAKA}

Arnold, H. J., \& Daniel C. Feldman.(1988). Organizational Behavior. New York: Mc GrawHi II Inc.

Arumugan, V.C.,\& Mojtahedzadeh, R. (2006).Measuring Customer Satisfaction with Service Quality Using American Customer Satisfaction Model (ACSI Model). International Journal of Academic Research in Bussiness and Social Science Vol 1. No.3

Bhaskara, R.A. (2011). Analisis Pengaruh Penerapan PrinsipTotal Quality Management terhadap Kepuasan Kerja Perawat Obstetri dan Ginekologi RSU Dr. Soetomo. Surabaya:Universitas Airlangga

Best, M.F., \&Thurston, N.E. 2004.Measuring NurseJob Satisfaction.Journal of Nurse Administration 34(6): 283-90

Ching, S., Ling, Y., \& Rong-Da. (2005). Effects of Job Rotation and Role Stress Among Nurse on Job Satisfaction and Organizational Commitment. BMC Health Service Research

Dale. (2003). Total Quality Management (Edisi Ketiga). New Jersey : Prentice Hall

Dose, J.J. (1997). Work Values: An Integrative Framework And Illustrative Application To Organizational Socialization. Journal of Occupational and Organizational Psychology $\mathrm{Vol} 70$

Gasperz, V. ( 2005). Total Quality Management (Terjemahan). Jakarta. PT. Gramedia Pustaka Utama 
Gibson, dkk. (2009). Organizational: Behavior Structure, Process. New York : The McGraw Hill Companies, Inc.

Hughes. 2012. Leadership: Memperkaya Pelajaran dari Pengalaman, edisi 7. Jakarta: Salemba Humanika

ljaz, A. 2012.Internal Customer Job Satisfaction and Role of TQM Practices.Far East Journal of Psychology and Business Vol. 6 No. 2 February 2012

Judge, T.A., \& Bono, J.E. (2000) Five Factor Model of Personality and Transformasional Leadership. Journal of Applied Psychology

Lawler, E.E., Mohrman, S.A., and Ledford, G.E., (1998).Strategies For High Performance Organizations - The CEO Report Employee Involvement, TQM, And Reengineering Programs In Fortune 1000 Corporations. San Fransisco: Jossey-Bass Publishers

Luthans, F. (2006).Perilaku Organisasi. Edisi Sepuluh. Yogyakarta: Penerbit Andi

Lowery, C.M., Beadles, N.A., and Carpenter, J.B. (2000). TQM's Human Resources Component. Quality Progress, Vol. 33. No. 2
Prasanti, A.A. 2015. Analisis Pengaruh Penerapan Prinsip Total Quality Management Terhadap Kepuasan Kerja Karyawan. Surabaya: Universitas Airlangga

Pisoulis, L., Migdalas, A., Pardalos, M., and Chinchuluun A. (2008).Pareto Optimality, Game Theory and Equilibria. Retrivied from http://books.google.com/books

Robbins, S.P. (2001). Perilaku Organisasi, Buku I Edisi 9. Jakarta: Gramedia

Siagian, P. (2005). Kiat Meningkatkan Produktivitas Kerja. Cetakan Pertama.Jakarta: PT. Rineka Cipta

Scarpello, V., \& Campbell, J. P. (1983). Job Satisfaction: Are All The Parts There? Pers. Psychology,36,577-600.

Tjiptono, F. (2003).Strategi Pemasaran. Edisi Kedua. Yogyakarta: Penerbit Andi

Wahyudi, T. 2010. Upaya Meningkatkan Kepuasan Kerja Karyawan di Rumah Sakit Muhammadiyah Surabaya. Surabaya: Universitas Airlangga

Yasin.(2001). Kepemimpinan dalam Pengembangan Organisasi.Jurnal Lintasan Ekonomi Fakultas Ekonomi Universitas Brawijaya Malang, Volume 18 Nomor 1, Malang 